\title{
UNDERSTANDING LOCAL POLITICAL BEHAVIOR: THE ROLE OF THE OLDER CITIZEN*
}

\author{
JoEL SMITH† \\ Herman Turk \\ Howard P. MYers $\$$
}

\section{INTRODUCTION}

A rather wide range of phenomena are suggested by the term "politics." Experts disagree considerably over what politics should or should not connote. Since it would not be possible to do justice to all of its aspects in a discussion of this length, it seemed reasonable to restrict the following consideration of the political role of the aged to some activities which are generally accepted as political. Our decision as to how to restrict our topic is conditioned also by (a) our interest in evaluating two alternative classical theories about the nature of the processes that lead to political arrangements; (b) the restricted nature of the new data we have to offer with respect to those theories; and (c) our own preference for enlarging the scope of phenomena with which most behavioral studies of politics deal. For all these reasons, our particular concern shall be individual behavior in local community political issues.

This behavior includes voting; holding of opinions on issues about which decisions are made in the political arena; and activities, conventionally recognized as political, that are ancillary to the outcomes of political decisions. Most studies of political behavior deal with voting or opinions-often without considering the two simultaneously. Studies of ancillary political activities-for example, campaigning, circulating petitions, attending meetings-are as rare as whooping cranes. In this sense, then, we hope to fill in the picture of that segment of political behavior in the United States in which all individuals have an opportunity to participate.

In addition to this restriction, our concern is with such behavior as it occurs in the local community and as it is concerned with local communal issues. Most of what we know about political behavior has to do with issues of state, regional, national or international scope. While it may be true, for example, that the same factors are associated with voting in both presidential and mayoralty elections, this is still a question to be assessed. There are, of course, reasons for supecting that the dynamics

* Data discussed in this article were obtained from research conducted under a grant from the Ford Foundation to Duke University for "Socio-Economic Studies for Aging."

†B.A. 1945, Queens College; M.A. 1950, Columbia University; Ph.D. 1954, Northwestern University. Associate Professor of Sociology, Duke University. Contributor to books and periodicals of articles on urban social organization, urban ecology, research methods, and mass communication.

¥B.S. I947, University of Nebraska; M.A. 1952, Columbia University; Ph.D. I959, American University. Assistant Professor of Sociology, Duke University. Contributor to periodicals of articles on sociological theory, formal organization, and small groups.

$\S$ B.A. $x 960$, San Diego State College. Research Assistant, "Community and Retirement," Duke University. 
of the local political situation and the behavior of the community's citizens in this context may be different. Mention need be made of only a few rather obvious differences in the two situations.

First of all, voting rates in strictly local elections are, almost without exception, notoriously lower than they are in national elections. Secondly, citizens are much more directly accountable to their peers for their behavior with respect to strictly local political issues-in the local community it is easier to know who each person is, where he stands, and how he acted. Thirdly, the individual has a wider variety of political decisions to cope with in local political affairs. On the national level it is easy to see one's choices as resting between persons, parties, and/or slogans. In the local arena, while these same decisions have to be made, often choices also have to be made among non-partisan candidates and among alternative courses of action on issues subjected to referenda.

Aside from these rather elementary observations that may be made by anyone who contrasts community and national politics, there is evidence from systematic research that strongly suggests discontinuity between the two processes. For example, in national elections the votes of the disaffected have been in favor of changes from ongoing trends, ${ }^{1}$ whereas at the local level votes for the status quo have been attributed to disaffection. ${ }^{2}$ Furthermore, two types of influence systems that coexist in local communities have been distinguished. One is local and the other cosmopolitan, and a different kind of person is instrumental in each. ${ }^{3}$ All in all, the weight of these observations favors the desirability of a fresh examination of local political processes in their own terms. Projections of generalizations based on the study of extra-community politics may not be justified.

The position of the aged in any political process is of special interest, particularly at a time when increasing portions of the American population fall into this category. The aged present a disquieting paradox in a society that subscribes to democratic ideology—a philosophy that rests on the faith that wise and proper political decisions are appropriately made only by the aggregate choices of a fully participating, fully informed electorate. Critics decry the fact that in a social system based on such a political philosophy, the structure operates in such fashion that large numbers of citizens do not participate, and even larger numbers are not adequately enough informed to participate effectively. The disquieting paradox of the aged stems from

\footnotetext{
${ }^{2}$ For an extensive review of such findings, see Lipset, Lazarsfeld, Bartin \& Linz, The Psychology of Voting: An Analysis of Political Behavior, in Gardner Lindzey (ED.), Handbook of Social Psychozogy I126, II34-50 (1954).

Summarized in Horton \& Thompson, Powerlessness and Political Negativism: A Study of Defeated Local Referendums, 67 AM. J. Sociology 485 (1962). Also see KuRt Lang, Collective Drwamics 413$22(196 \mathrm{r})$.

- See Rogert K. Merton, Social Theory and Social Structure 387-420 (I957).

'See Hyman \& Sheatsley, The Current Status of American Public Opinion, in D. KATZ, D. CArTwright, S. Eldersvield \& A. Lee (Eds.), Public Opinton and Propaganda 33-48 (i954); Lazarsfeld \& Merton, Mass Communication, Popular Taste, and Organized Social Action, in G. SwANson, T. NEwcomb \& E. Hartley (Eds.), Readings in Soctal Psychology 74-85 (1952); D. Riesman \& R. Denney, Do the Mass Media Escape from Politics?, in B. Berelson \& M. Janowitz (Ens.), Reaner in Puslic Opinion and Communication 327-33 (1953).
} 
the fact that while they are the one group in society most likely to have the time and experience to participate in politics effectively, they seem to be largely inactive, incompetent, and disengaged from political concerns. 5 This situation warrants special examination of the political behavior of the aged not only because of its pragmatic significance, but also because it should yield strategic evidence as to the relative applicability of the two major alternative models of political process that have attracted the major thinkers throughout the intellectual history of Western civilization.

Two Alternative Models of Political Process

The first of these models views the electoral scene as a market place characterized by the rational adjustment of competing interests held by various individuals and sub-groups. Here the resolution of issues is either a function of the preponderance of certain self-oriented interests over other interests in an anonymous social situation or of the relative ability of various sub-groups to command the political conformity of their members or of the relative strengths of certain coalitions compared to those of other coalitions. This can be called a segmental or self-interest model ${ }^{0}$ of issue participation, and it has predominated in empirical studies of political behavior. Its main strength is in explaining-though not perfectly-why participation is on one side of an issue rather than on another. However, it is inadequate for explaining why there should be participation at all.

The second model, which can be called civic responsibility model, views political participation as an obligation dictated by the standards of a social whole that is divided on how best to achieve the common interests of its members. It has received little attention in empirical research. While such a model may be a good predictor of participation rates, it has appeared to be an insensitive predictor of the direction of such participation. Both conceptual models seem necessary if the concrete democratic process is to be understood fully. Concern with the second of these models is occasioned by its relative neglect in other studies, rather than by any conviction that it is the more salient of the two under all circumstances.

II

\section{Related Views of Society, the Individual, and the Urban Community}

The political process occurs within the framework of a society or a community, and therefore must be understood in terms of organized social life and the behavior of the individuals who comprise society. When the political process is viewed in these terms, it may be seen that the two alternative models of political participation

${ }^{5}$ See Lipset et al., supra note I, at II26-34; Elaine Cumming \& Wriliare E. Henry, Growing Old 75-105 (I96r); and SAmuel Stouffer, Communism, Conformity, and Civil Liberties 93 (1955).

- For example, see W. E. Binkley \& M. C. Moos, A Grammar of Politics: The National, State, AND Local GovernMents 3-8 (1949).

'For example, see A. Lawrence Lowell, Public Opinion and Popular Government 8-15 (1926). 
are likely to have had their genesis in two classic issues, the first of which pertains to the nature of the bonds that hold the body social together and the second of which addresses itself to the motivation of the individual.

Society has been seen as having either or both of two principal mechanisms of integration. The first follows a quasi-economic argument and is best exemplified by such early social contract philosophers as Hobbes and Rousseau. Social order is viewed as the outgrowth of the competition for power, the adjustment of selfish ends, and a division of labor in which contracts are entered into for purposes of mutual protection and mutual gain. Certain positions in psychology which consider man as biologically determined can most readily be linked to this conception of social reality. Both the behavioral psychology of Pavlov and Watson and the psychoanalytic orientations of Freud consider human behavior to be self-gratifying and self-protective. Society is seen either as reducible to the total of such strivings by its individual members or as a constraint which is placed upon them so that humanity will not revert to the jungle.

The second major perspective views social life as organized by what Comte has called universal consensus and what Durkheim labeled the collective conscience. This position implies that, for the greater part, societies or communities are held together through unity of outlook, identification with the whole, and a common morality. Linked to such a concept of society are psychologies which suggest that society is an inextricable part of the individual's self. Such psychologies appear in the works of Cooley and Mead, who suggested that if the self is shaped by the society, then commitment to the standards of that society is a means of selfrealization. Freud's concept of the superego tends a little towards such a psychology, but its definition as a coercive force brings it only halfway between the two extreme positions we are considering. Few contemporary scholars would support the one position to the exclusion of the other, but in terms of the relative emphasis to be placed in each, the conceptual polarity is still very much alive.

Traditionally the urban community has been examined to a large extent in terms of the quasi-economic model. Park and Burgess's ${ }^{8}$ classic studies depicted the city as a product of competition for the use of land giving rise to processes of ethnic and occupational invasion or succession. Accompanying this picture of urban social structure there has emerged a picture of the isolated, rootless, amoral city dweller, ${ }^{9}$ who resolves his state either by self-service or by self-destruction. Recently, however, this picture of a utilitarian city with its overindividualized citizen has been said to apply fairly closely only to certain cites and less well to others. ${ }^{10}$ Different cities are

${ }^{8}$ See Park, The Urban Community as a Spatial Pattern and a Moral Order, in E. C. Hughes ET AL. (EDs.), Human Conmuniries 165-77 (1952). See also Burgess, The Growth of the City: An Introduction to a Research Project, in R. E. Park, E. W. Burgess \& R. D. McKenzie (Eds.), The CitY 47-62 (1925).

- See Komarovsky, The Voluntary Associations of Urban Dwellers, Ir AM. Sociological REv. 686 (I946); Cohen, Los Angeles Rooming-House Kaleidoscope, I6 id. 3I6 (I95I); and HarvEY W. Zorbaugh, The Gold Coast and the Slum: A Soctologicat Study of Chicago's Near North Side 69-86 (1929).

${ }^{10}$ For example, see Angell, The Moral Integration of American Cities, 52 AM. J. Socrorogy I passim (No. I, Pt. 2) (I95I); and WALter Ftrey, LiNd Use in Central Boston passim (1947). 
said to have different bases of integration; some rest on a base of competition, individualism, and economic interdependence but others rest on tradition, pride, and an altruistic or dedicated citizenry. In short, it is likely that studies of participation in various aspects of urban life must consider both models.

III

\section{Local Election Studies}

The few studies which have been concerned with behavior on local issues seem to view the city either as a collection of competing interest coalitions or as composed of a politically apathetic mass that can sometimes be activated in a protest vote. Formulae have been developed for predicting the resolution of an issue on the basis of the number of economic or political groups for and against a proposal and the amount of cooperation in each camp. ${ }^{11}$ Voter turnout, then, is seen as an indication of the effectiveness of such coalitions. Studies of school bond elections and fluoridation votes, on the other hand, suggest that, by and large, urban dwellers are politically disinterested. However, every so often they see themselves as the "outs" in a fit of near-Marxist class-consciousness and rise against measures viewed as the property of the "ins."12 In short, such studies employ a utilitarian, individualist model of the city and a self-interest model of political process that shows promise of being able to predict the turnout for and the resolution of certain kinds of issues.

However, the self-interest model does not explain a major finding in a recent study of habitual voting patterns in St. Louis. ${ }^{13}$ Here it was suggested that persons who voted in more local elections than did others also tended to vote in a greater number of less local and national elections, and that persons who did not vote in national elections tended not to vote in any election. Since the more local the election, the more likely it is to involve citizen self-interest directly, self-interest seems to be an inadequate explanation of such voting patterns. Moreover, if the apathy arising out of social isolation can account fully for non-participation in voting, then, by the same reasoning, one would expect city dwellers to be even more apathetic about national elections than about local ones.

What is missing in these local election studies is any hint that people might vote because they feel they should vote and that differential political participation might be explained, at least partially, in terms of differential access to norms of civic responsibility. The nature of many local issues also bears mention. Voting for school bond issues, hospital financing, fluoridation, urban renewal, and other such projects may be viewed as a vote for community "progress." What is important to note is that a vote for progress is an identification of one's own interests with

\footnotetext{
${ }^{11}$ Examples of this approach may be found in Hanson, Predicting a Community Decision, 24 Am. Sociological Rev. 662 (1959); and Miller, The Prediction of Issue Outcomes in Communify Decision Making, in 25 Proceedings of the Pacific Sociological Societr 137-47 (r957).

12 Horton \& Thompson, supra note 2, passim; LANG, op. cit. supra note 2, at 418-21; and Wilensky, Life Cycle and Formal Paticipation, in R. W. Kleemeier (ED.), Aging nNd Leisure 239 (1961).

${ }^{18}$ John C. Bolzens (Ed.), Exploring, the Metropolitia Community 184-85, 430-31 (196r).
} 
those of the city as a whole, not any of its interest factions. Since sacrifices are required, it may be considered a vote against immediate self-interest. Hence, the civic responsibility model may help to explain the direction as well as the fact of voting in local elections.

\section{IV}

\section{Voting Models and the Aged Voter}

Studies of the political behavior of the aged suggest that old people are radical, ${ }^{14}$ conservative, ${ }^{15}$ or unresponsive in their political behavior. Their conservatism has been attributed to their vested interests in the status quo, their radicalism to their opposition to a society which rejects them, and their unresponsiveness to their senility or their normlessness. Only the latter observation suggests that political participation may have a moral base, a point to which we shall return.

Studies of national elections have depicted the self- or subgroup-oriented voter as largely apathetic. He votes if "opinion leaders" point out to him that his interests are best served by doing so. He refrains from voting while under cross-pressures. His feelings of responsibility to vote are largely irrelevant. Explanations of the low rate of voting by old persons are of the same order. It has been uncritically attributed to the absence of interest groups for the aged, the inconsistent status positions that create cross-pressures (e.g., the habitual Republican with a sharply reduced socioeconomic status), and the separation from both job and disabled contemporaries that separates the aged from the opinion leaders. Such explanations have been assumed, but have not been tested.

The notion that the normless person does not vote, however, involves use of the concept of anomie (normlessness). This provides the first clue that people may sometimes vote simply because they feel they should. Since it has, indeed, been established that persons high in anomie vote less than non-anomic persons, ${ }^{16}$ a moral base for voting is implied. In so far as morality must constantly be renewed through social interaction, the aged, with their attenuated social contacts, become an anomic group. Thus, not only their non-voting, but also their non-support for "progressive" proposals might be explained in terms of disengagement from the total social system, rather than in terms of sub-group pressures that cause votes one way or another, or place the aged in conflict. Besides being a paradoxical problem group for the polity, then, old persons become strategic research subjects in the application of the civic responsibility model of voting behavior.

16 Lipset et al., supra note $x$, at Ir 49-50.

${ }^{15}$ H. J. Eysenck, The Psychology of Politics 21 (I954); Bernard R. Berelson, Paut F. Lazarsfeld \& William N. McPhee, Voting 33I (1954); Stouffer, op. cit. supra note 5, at 89; Paul E. Inzarsfeld, Bernard R. Berelson \& Hazel Gaudet, The People's Choice 23-4 (1944); Cottrell, Governmental Functions and the Politics of Age, in Ciark Tibbets (ED.), Handbook of Sociar. Gerontology: Societal Aspects of Aging 66I (ig6o); Angus Campbell, P. E. Converse, Warren E. Miller \& Donald E. Stokes, The American Voter 2xo-xi (ig6o).

${ }^{20}$ 'See Robert E. Lane; Poltrical Life i68 (I959); and Arthur Kornínausé, Harold L. Sheppard \&*Albert.J. Mayer, When Labor Votes i 89-200 (1956). 


\section{$\mathrm{V}$}

Local Political Behavior from the Standpoint of Civic Responsibility Moded

The discussion to follow will assess the value of the civic responsibility model in understanding local political behavior. If it can be shown to apply to one urban community, its relevance to other communities must then receive careful consideration. This model suggests that the more fully the individual is tied in with various aspects of the life of the community, the more likely he is to vote and to participate in other political actions. The corollary to this is that the aged person who remains highly implicated in the social life of his community will participate as much as other such persons and that the aged who are not so implicated will participate no less than their younger counterparts. These twin predictions are predicated on the notion that rather thorough implication in the community creates and supports a sense of civil responsibility. If so, the relationship between age and political participation must be seen in these terms.

The holding of opinions is the more passive side of the political process. If the above argument is correct, analogously, one might expect that holding any opinion on an issue is associated with community implication as defined above. Similarly, the tendency to support "community progress" should increase with increases in such community implication. Therefore, age may be related to holding an opinion per se, and to holding a "progressive" opinion, only in so far as age affects the chances for being implicated in the total social life of the community.

\section{VI}

\section{The CoMmunity aNd the SaMple}

Answers to the questions we have been raising concerning the political processes of local communities and the role of the aged therein require information on the political behavior of community members. Such information was available as a part of a larger inquiry into the community roles of the aged. This study involved extensive interviews with residents of Durham, North Carolina, an industrial working class community having a population in 1960 of 78,302 . It differs from most other southern cities of its size in at least two major respects. For one thing, the Negro community appears to be quite highly organized politically, economically, and socially, having its own college, the world's largest Negro insurance company, and a sizable middle class. For another, Durham is also the seat of a university with a strong national rather than local orientation, one that includes many non-local students and faculty members. Though it is a source of pride for Durham residents and important to the local economy, ideationally the university is in many ways a self-contained community only loosely linked to Durham proper.

As a southern city, Durham has (or must be assumed to have), a predominantly one-party political system, a shifting set of social standards that tends to define which elements of the population should not participate politically (e.g., women and 
Negroes), and a generally low level of political participation. ${ }^{17}$ These considerations suggest that different social segments of the community live in different social worlds vis-à-vis politics, and, hence, that analysis be restricted to individuals who share a relatively homogeneous social environment. For this reason, Negroes, women, and persons from the most socioeconomically deprived areas of the city were excluded from the analysis.

Two samples were drawn from all non-Negro, non-slum census tracts in Durham. The first was a random sample of persons between ages 21 and 64 based on the city directory. The second was a sample of persons $6_{5}$ and over which was obtained from a random selection of street segments, in each of which all households were canvassed; one old, but physically able, person was selected from each household containing such persons. Additionally, those who had not lived in Durham long enough to have participated in all of the issues considered in the study were excluded from both samples. The two samples will be called the "general sample" and the "old sample" and include 76 and 44 men respectively.

Members of both samples were interviewed in their homes through use of an extensive schedule. Information was obtained about such matters as residential history; work history; attitudes about the community; familial, religious, and associational participation patterns; sources of information about community affairs; perceptions of the community power structure; self-images; and the nature and extent of participation in political matters. The interviews, which lasted $2 \frac{1}{2}$ hours on the average with the general sample and $3 \frac{1}{2}$ hours with the old sample, were conducted in the Spring of rg6r.

\section{VII}

\section{Some Verification of Previous Findings}

Certain variables have been found to be relatively consistent predictors of voting rates. In the present research, it proved possible to check whether Durham is unusual in any of these respects. Table one shows voting rates for selected subgroupings of the combined samples before the women were removed. ${ }^{18}$

Voting rates were determined from respondents' replies to questions about whether they had ever voted in a local election or in a local primary, and whether they had voted on a specific proposal to unify city and county governments, or on a specific school bond proposal. With very few exceptions, persons who voted on the last issue also voted on the other three; those who voted on unification also voted in primaries and local elections; and those who voted in primaries also voted in local elections. This meant that, as in the St. Louis study, voting versus non-voting is a generalized tendency, and not just "issue-specific."10 The table presents the extent to which each sub-group voted in these four instances, counting one for each affirmative response to the questions on voting.

${ }^{17}$ See V. O. Key, Southern Politics in State and Nation passim (1949).

${ }^{18}$ Old persons are disproportionately represented in such a combined sample, but a more complex sample-by-sample analysis does not alter the relationships reported in Table I.

10 Bollens, op. cit. supra note 13 , at $184-85,430-31$. 
TABLE I

Maan Extent of Voting in Selected Sub-groups of the Combined Samples

\begin{tabular}{|c|c|c|}
\hline Sub-group Characteristics & Number of Respondents & Mean Extent of Voting \\
\hline 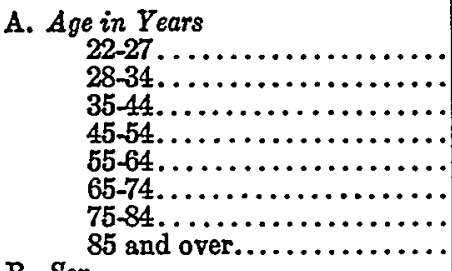 & $\begin{array}{r}20 \\
27 \\
54 \\
59 \\
33 \\
94 \\
35 \\
7\end{array}$ & $\begin{array}{l}1.65 \\
2.08 \\
2.50 \\
2.51 \\
2.24 \\
1.86 \\
1.54 \\
0.71\end{array}$ \\
\hline $\begin{aligned} \text { B. Sex } & \\
& \text { Male } \ldots \ldots \ldots \ldots \ldots \ldots \ldots \ldots \ldots \ldots \ldots \ldots \ldots \ldots\end{aligned}$ & $\begin{array}{l}120 \\
209\end{array}$ & $\begin{array}{l}2.54 \\
1.79\end{array}$ \\
\hline 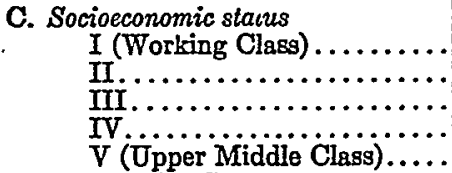 & $\begin{array}{l}26 \\
85 \\
96 \\
57 \\
65\end{array}$ & $\begin{array}{l}0.92 \\
1.71 \\
1.79 \\
2.53 \\
3.00\end{array}$ \\
\hline 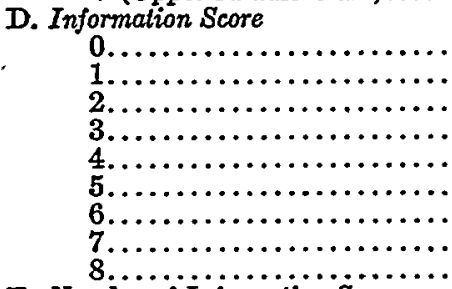 & $\begin{array}{l}12 \\
10 \\
11 \\
13 \\
19 \\
46 \\
53 \\
81 \\
81\end{array}$ & $\begin{array}{l}0.25 \\
0.60 \\
0.09 \\
1.00 \\
1.21 \\
1.54 \\
2.15 \\
2.48 \\
2.95\end{array}$ \\
\hline 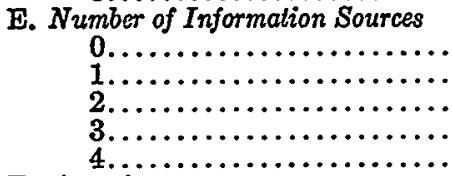 & $\begin{array}{r}11 \\
60 \\
113 \\
115 \\
30\end{array}$ & $\begin{array}{l}0.36 \\
1.10 \\
1.99 \\
2.55 \\
3.07\end{array}$ \\
\hline $\begin{array}{l}\text { F. Anomie } \\
\quad \begin{array}{l}\text { Present. } \\
\text { Absent. }\end{array} \quad \ldots \ldots \ldots \ldots \ldots \ldots \ldots \ldots \ldots \ldots \ldots \ldots\end{array}$ & $\begin{array}{r}60 \\
269\end{array}$ & $\begin{array}{l}1.70 \\
2.15\end{array}$ \\
\hline Totat Sampize. $\ldots \ldots \ldots \ldots \ldots \ldots$ & 329 & 2.07 \\
\hline
\end{tabular}

Part $A$ of the table shows that voting increases with age up to advanced middle age and then decreases. ${ }^{20}$ For our purposes, the fact that age is associated with voting behavior in Durham, much as it has been found to be elsewhere, is strategic. It suggests that the explanation for this phenomenon in Durham may also apply to other cities.

Parts $B$ and $C$ of table one also suggest that voting patterns in Durham are not unusual. Here as elsewhere men vote more than women and voter turnout increases with socioeconomic status (i.e., income and occupational prèstige). ${ }^{21}$ Part $D$ refers to a community information score given to the respondents. They were asked whether they had heard of such events as possible disbandment of the local baseball team, an old-age housing plan, fluoridation of the city water supply, and the

${ }^{20}$ See Lipset et al, suṕra' note $\mathrm{I}$, at'II27; and CAMpBeLI 'ET'AL., op. cit. supra note I5.

${ }^{21}$ Ibid. 
like, and were scored one for each such event they knew. This relationship between information and voting has been established in the literature and also appears here. ${ }^{22}$ Part $E$ of the table confirms other findings that the greater the number of sources of information used by the respondent the more likely is the person to vote. ${ }^{23}$ Information sources enumerated in this section are: personal acquaintance with at least one community power figure, personally knowing an individual of symbolic significance in the city, local newspaper readership, and radio listenership. The higher this index, the higher the voting rate turns out to be.

Finally, respondents were classified as anomic if they indicated that they were subjectively disengaged from society in answer to a question about the importance to the community of what they do and/or if they gave no social value or social status references in answer to the inquiry, "How would you answer the question 'Who am I' in three sentences?" Fairly graphic examples of the former include statements such as:

"I'm just a small cog in a big machine."

"Sometimes I feel like I don't mean anything to anybody."

"I'm not important to anyone. ..."

The latter is illustrated by:

"Someone in the way. Nothing else."

"I don't know. I'm me. I'm just an ordinary person."

"I can't think of anything to describe me."

"I can't answer that. I'm an average person."

All other respondents were called non-anomic, in the absence of evidence to the contrary. Part $\mathrm{F}$ of table one shows that anomic persons voted less on the average than those who were non-anomic. Despite the crudeness of the measurement of anomie, a rather general observation is confirmed. ${ }^{24}$

In Durham, then, age, sex, socioeconomic status, information, information sources, and anomie are associated with the voting rate, much as they are elsewhere. Aside from the support for these somewhat routine contentions that the data offer, they do take us part way toward the theoretical question of concern, for both the observed generalizability of voting versus non-voting, and the relationship between anomie and voting suggest the applicability of the civic responsibility model.

\section{VIII}

\section{Polittcal Participation by Males of Different Ages}

The men in our study have been divided into three groups: those under 40, those between 40 and 64 , and those of the old sample. Hereafter, these groups will be referred to as "young," "middle-aged," and "old." This division "was necessary

${ }^{29}$ See Sykes, The Differential Distribution of Community Knowledge, in PaUL K. Hatr \& AlBERT J. Reiss (Eds.), Ctries and Society: The Revised Reader in URban Sociology 715-I6 (x957).

${ }^{23}$ Lipset et al., supra note $\mathrm{r}$, at Ir40.

24 LANE, op. cit. supra note I6, at I68; KORNHAUSER ET AL., op. cit. supra note I6, at-I89-95. 
to provide sufficient numbers of cases for analysis in each category. Table two shows a similar rising and descending trend of voting by age to that reported for the total sample, the aged men voting least of all.

We might assume that other kinds of political participation would display a similar ordering of age groups. Therefore, respondents were evaluated in terms of a number of other political activities in which they may have engaged. ${ }^{25}$ Table three shows the distribution of the number of such activities engaged in by members of each age group. Here the youngest men are the most active, while the oldest men also again display the lowest level of political activity.

TABLE II

Voting Rates of Males in Three Age Groups

(Per Cent)

\begin{tabular}{|c|c|c|c|}
\hline \multirow{2}{*}{ Extent of Voting } & \multicolumn{3}{|c|}{ AGE IN YeARB } \\
\hline & $22-39$ & $40-64$ & 65 and over \\
\hline 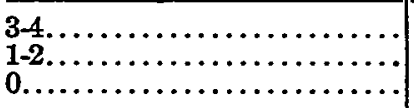 & $\begin{array}{l}62 \\
22 \\
16\end{array}$ & $\begin{array}{r}77 \\
8 \\
15\end{array}$ & $\begin{array}{l}52 \\
23 \\
25\end{array}$ \\
\hline Total... & 100 & 100 & 100 \\
\hline (Number of Respondents)....... & (37) & (39) & (44) \\
\hline
\end{tabular}

TABLE III

Political Activities (Other Than Voting) of Males in Three Age Groups

(Per Cent)

\begin{tabular}{|c|c|c|c|}
\hline \multirow{2}{*}{$\begin{array}{c}\text { Number of Political Activities } \\
\text { (Other Than Voting) }\end{array}$} & \multicolumn{3}{|c|}{ AGE IN Yearg } \\
\hline & $22-39$ & $40-64$ & 65 and over \\
\hline 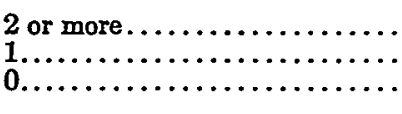 & $\begin{array}{l}32 \\
46 \\
22\end{array}$ & $\begin{array}{l}33 \\
23 \\
44\end{array}$ & $\begin{array}{l}16 \\
27 \\
57\end{array}$ \\
\hline Total.... & 100 & 100 & 100 \\
\hline (Number of Respondents)...... & (37) & (39) & (41) \\
\hline
\end{tabular}

Another generalization that has been made about the older citizen is that, in the absence of specific relevance to his interests (e.g., old age assistance, specific demagogic appeals), he will be less likely than others to have formed an opinion on a political issue. ${ }^{26}$ If he does form an opinion, that opinion is usually char-

${ }^{25}$ These activities included: working for their side in a local vote, having given an opinion on an issue when asked, having signed a petition, belonging to a political group, having taken sides on a local issue.

${ }^{20}$ Wilensky, supra note 12, at 237-39. 
acterized as conservative. ${ }^{27}$ Four recent political issues in Durham were proposals for social change: fluoridation of the water supply, city-county government unification, urban renewal, and downtown shopping center redevelopment. A count of the number of opinions for, the number of opinions against, and the number of "no-opinions" within each age group yielded the information contained in table four. It may be seen that the two younger age groupings display higher rates of opinion formation and greater endorsement of change. However, the rate of opinion formation opposing change does not vary with age, contrary to the usual generalizations. This suggests the inadequacy of a rationalistic "conflict of interests" model in explaining age differences in opinion; since, if there were such conflict, not only should affirmations of change decrease with age, but also opposition should increase.

Finally, the adequacy of the civic responsibility model in explaining age differences in political behavior can be assessed by predicting that old men would be more anomic than young or middle-aged men. ${ }^{28}$ Table five tests this assertion and shows that the older men are indeed the most anomic. In summary, then, in Durham advancing age is associated with increased anomie, decreased political

TABLE IV

Progressivism of Opinions on Politicaz Issues Heid by Males in Three Age Groups (Per Cent)

\begin{tabular}{|c|c|c|c|}
\hline \multirow{2}{*}{ Opinion } & \multicolumn{3}{|c|}{ AGE IN YEARB } \\
\hline & $22-39$ & $40-64$ & 65 and over \\
\hline 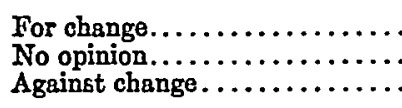 & $\begin{array}{l}48 \\
26 \\
26\end{array}$ & $\begin{array}{l}49 \\
26 \\
25\end{array}$ & $\begin{array}{l}35 \\
40 \\
25\end{array}$ \\
\hline Total.... & 100 & 100 & 100 \\
\hline (Number of Responses)...... & (148) & (156) & (176) \\
\hline
\end{tabular}

TABLE V

Incidence of Anomie Among Males in Three Age Ranges (Per Cent)

\begin{tabular}{|c|c|c|c|}
\hline \multirow{2}{*}{ Anomie } & \multicolumn{3}{|c|}{ Age IN Years } \\
\hline & $22-39$ & $40-64$ & 65 and over \\
\hline 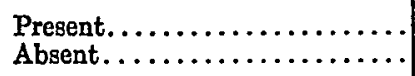 & $\begin{array}{l}16 \\
84\end{array}$ & $\begin{array}{l}10 \\
90\end{array}$ & $\begin{array}{l}25 \\
75\end{array}$ \\
\hline Total............. & 100 & 100 & 100 \\
\hline (Number of Respondents)...... & (37) & (39) & (44) \\
\hline
\end{tabular}

${ }^{27}$ Ibid.; STOUFFer, op. cit. supra note 5 , at 89-ro2.

${ }^{28}$ Wilensky, supra note 12, at 239; LANE, op. cit. sspra note 16 , at 168-69. 
activity of all kinds, and an increased tendency to have no opinion or not to support proposed changes.

\section{IX}

\section{Community Implication and Political Participation}

The frame of reference in which the present research was conducted required that voting and other political behavior be examined as a potential function of the extent to which a resident was thoroughly implicated in the on-going social life of this community. Three ways in which community residents may be so implicated to a greater or lesser degree were selected for analysis.

Some persons have greater commitment to remain residents in the community than others. At the extreme, some persons find they must stay irrespective of whether they desire to leave. A vivid example of this condition is provided by a fifty-sevenyear-old widow who lacks income, and lives with a son whose works keeps him here. Such a person, though free, is tied to the community almost as thoroughly as a prison inmate. Conversely, others have to leave regardless of how much they may wish to stay. This phenomenon receives an almost classic illustration in the case of a fortyeight-year-old spinster whose only retirement resource is a home for retirees maintained in another city by an association to which she belongs.

The respondents were scored according to how committed to stay each one was. The extreme scores referred to respondents whose choices as to place of residence were determined in one direction or the other by situational factors no longer under their own control-those forced to leave and those constrained to stay, respectively. Others received plus one on the commitment score for each of the following attributes: owning a home, having long tenure with current employer, having children in high school, feeling directly responsible for the care of another Durhamite (not in one's own household), and having all or most of one's friends in Durham. The commitment score could, therefore, range from 0 to 7 .

Another way in which persons demonstrate the extent of their implication in the ongoing social life of the community is in terms of the intensity and extent of their participation in the various matrices of social contact available in the community. A social anchorage score was constructed by scoring one for each of ten behavior patterns actually manifested. ${ }^{2 \theta}$ The total score could range from $\circ$ (no anchorages) to ro (high anchorages).

The first two measures of community implication refer largely to objective aspects of social structure and behavior. The third refers more to subjective dispositions. An index of community-orientation separated persons who said they thought, felt, and acted in terms of the entire community from those who responded

\footnotetext{
${ }^{20}$ These included the following broad categories of social activity: using mass media; lcisure and recreation; participation in voluntary associations; work; the community; school; family; religion; friendships; and neighborhood. It may be seen that the last four refer most clearly to segments of the community only; however, scores based on these were so closely associated with those based on the remaining attributes that all were combined into a single score.
} 
only in terms of segments of the community or in terms of the advantages and disadvantages the community had for them personally. ${ }^{30}$

These three aspects of how individuals are related to the community were found to be associated with one another in an interesting pattern--one which made it possible to combine them into a single index. Almost all persons who were community-oriented had a social anchorage score greater than six and a commitment score greater than three. Almost all persons with a social anchorage score greater than six also had a commitment score greater than three. In other words, the majority of the respondents (eighty-six per cent) displayed one of the following patterns of implication: high in all three, high anchorages and high commitment only, high commitment only, low in all three. Such patterning supports, though it does not prove, the possibility that social anchorages form on the basis of commitment, such anchorages leading to community orientation. The four types of patterns were scored $4,3,2$, and $\mathrm{I}$, respectively, in an index of community implication, with deviant patterns being assigned one of these scores by standard procedures.

If community implication and anomie are correlates of civic responsibility, it is to be expected that non-implication is associated with anomie. This is borne out by the information in table six. Small numbers of cases are probably responsible for the absence of a perfect linear relationship between the two variables, but, in general, the results suggest that non-implication and anomie are closely associated, and that henceforth the community implication index can-among other thingssafely substitute for the relatively insensitive measure of anomie that was available.

The first prediction that could be made on the basis of this index is that the greater the community implication, the higher is the rate of voting. Table seven shows strong confirmation of this prediction for the combined samples. Almost all of the most highly implicated persons voted regularly, whereas less than one-third

TABLE VI

Extent of Anomie Manifested in Groups with Different Degrees of Community IMpLication

(Per Cent)

\begin{tabular}{|c|c|c|c|c|}
\hline \multirow{2}{*}{ Anomie } & \multicolumn{4}{|c|}{ Commonity Implication Type } \\
\hline & 4 & 3 & 2 & 1 \\
\hline 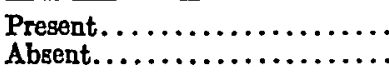 & $\begin{array}{r}9 \\
91\end{array}$ & $\begin{array}{l}15 \\
85\end{array}$ & $\begin{array}{l}10 \\
90\end{array}$ & $\begin{array}{l}38 \\
62\end{array}$ \\
\hline Total... & 100 & 100 & 100 & 100 \\
\hline (Number of Respondents) .. & (23) & $(40)$ & (31) & (26) \\
\hline
\end{tabular}

${ }^{\circ 0} \mathrm{~A}$ person was defined as community-oriented if he indicated participation in non-political civic activities such as volunteer welfare work, community planning, or charity drives, and who expressed positive (or negative) evaluations of Durham's over-all attributes (e.g., progressive-nonprogressive, friendly-unfriendly people) or because they said people should act and feel in these ways. All other persons were classified as noncommunity-oriented. 
TABLE VII

Voting by Members of Groups with Different Degrees of Community Implication (Per Cent)

\begin{tabular}{|c|c|c|c|c|}
\hline \multirow{2}{*}{ Extent of Voting } & \multicolumn{4}{|c|}{ Comardity Inplioation TXpD } \\
\hline & 4 & 3 & 2 & 1 \\
\hline 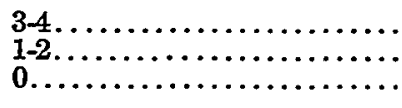 & $\begin{array}{r}96 \\
0 \\
4\end{array}$ & $\begin{array}{l}73 \\
16 \\
11\end{array}$ & $\begin{array}{l}50 \\
21 \\
29\end{array}$ & $\begin{array}{l}29 \\
34 \\
37\end{array}$ \\
\hline ……............. & 100 & 100 & 100 & 100 \\
\hline (Number of Respondents) ..... & (24) & (44) & (28) & (24) \\
\hline
\end{tabular}

of the least implicated persons did so. Moreover, the rate of non-voting decreased with greater community implication.

Turning now to other forms of political participation, a similar prediction was made: the greater the community implication, the greater the participation in nonvoting aspects of the political process. Table eight strongly supports this prediction also. As community implication lessens, the rate of non-participation rises from one out of six to almost two out of three.

Finally, if an opinion for change means a pro-community opinion, then the rate of having an opinion should be higher with higher community implication and such opinion should be more in favor of change. Table nine demonstrates this to be the case. The rate of no opinion increases with lower community implication while the rate favoring change decreases. The rate of opposition to change remains the same for all degrees of community implication. This suggests that the unimplicated person does not oppose change, he just does not support it. Perhaps, then, the word "change" could be replaced by the phrase "welfare of the community."

The intimate relationships between community implication and the extent and nature of political participation speak strongly for the predictive value of a civic responsibility model in local political processes. This would be the case if the

TABLE VIII

Political Activity (Other Than Voting) of Groups with Different Degrees of Community Implication

(Per Cent)

\begin{tabular}{|c|c|c|c|c|}
\hline \multirow{2}{*}{$\begin{array}{l}\text { Number of Political Activities } \\
\text { (Other than Voting) }\end{array}$} & \multicolumn{4}{|c|}{ Comarunity Implication Type } \\
\hline & 4 & 3 & 2 & 1 \\
\hline 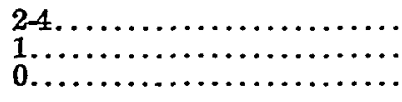 & $\begin{array}{l}62 \\
21 \\
17\end{array}$ & $\begin{array}{l}32 \\
43 \\
25\end{array}$ & $\begin{array}{r}7 \\
32 \\
61\end{array}$ & $\begin{array}{r}8 \\
29 \\
63\end{array}$ \\
\hline Total........ & 100 & 100 & 100 & 100 \\
\hline (Number of Respondents)..... & (24) & $(44)$ & (28) & (24) \\
\hline
\end{tabular}


TABLE IX

Extent of Progressivism Manifested by Groups with Differing Degrees of Community Implication

(Per Cent)

\begin{tabular}{|c|c|c|c|c|}
\hline \multirow{2}{*}{ Opinion } & \multicolumn{4}{|c|}{ Coumunity Impircation Type } \\
\hline & 4 & 3 & 2 & 1 \\
\hline 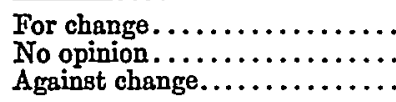 & $\begin{array}{l}59 \\
14 \\
27\end{array}$ & $\begin{array}{l}45 \\
29 \\
26\end{array}$ & $\begin{array}{l}37 \\
39 \\
24\end{array}$ & $\begin{array}{l}31 \\
44 \\
25\end{array}$ \\
\hline Total............ & 100 & 100 & 100 & 100 \\
\hline (Number of Responses) ..... & $(100)$ & (171) & (109) & (100) \\
\hline
\end{tabular}

community is one which has norms supporting political participation for the sake of community welfare. In such a case, the implicated person would not only be more likely to learn and internalize these norms but also have greater access to the channels available for implementing them. We feel that such norms are more and more prevalent in contemporary American communities-Durham included. Such a situation comports well with the community responsibility model.

\section{$\mathrm{X}$}

\section{Community Implication and the Political Participation of Older Men}

The Durham survey findings support a picture of politically inactive older men, who are less likely than others to support community change but who are no more likely than others to oppose it. They also suggest that political activity, as well as the support given to community change (but not its rejection), are closely linked to degree of objective and subjective immersion in the total life of the community. However, our argument leads us to expect that older men are the political men that they are, only in so far as they are, on the average, less implicated in the community than others.

TABLE $\mathrm{X}$

Community Implication Among Males in Three Age Ranges (Per Cent)

\begin{tabular}{|c|c|c|c|}
\hline \multirow{2}{*}{ Community Implication Type } & \multicolumn{3}{|c|}{ Age IN Years } \\
\hline & $22-39$ & $40-64$ & 65 and over \\
\hline 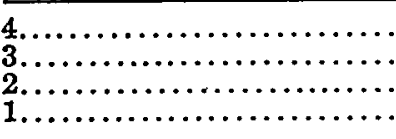 & $\begin{array}{r}16 \\
62 \\
8 \\
14\end{array}$ & $\begin{array}{l}28 \\
46 \\
16 \\
10\end{array}$ & $\begin{array}{r}16 \\
7 \\
43 \\
34\end{array}$ \\
\hline Total............ & 100 & 100 & 100 \\
\hline (Number of Respondents)...... & (37) & (39) & (44) \\
\hline
\end{tabular}


Table ten demonstrates that the old sample was indeed less community-implicated than were the other two age groupings. Three-quarters of the young and middleaged samples were in the two highest implication types, whereas three-quarters of the old sample were in the two lowest ones. If, then, the older persons were to be compared to others with like degrees of community implication, might not their political behavior be quite like that of the others?

Table eleven shows that, among persons similarly implicated, old persons are as likely as others to be regular voters. Table twelve concerns other political activities and leads to similar conclusions. Older persons are equal to middle-aged persons in their rates of non-voting participation.

The opinions that were expressed with respect to the four proposed changes show a comparable pattern. (See table thirteen.) The community-implicated old men differed little from other community implicated men in the responses that were made. Congruently, older men who were not implicated were like similar middle-aged men.

While it has been argued that all these observations are consistent with, and even predictable from, the community responsibility model, it might still be contended

TABLE XI

Voting by Age and Communtry Implication (Per Cent)

\begin{tabular}{|c|c|c|c|c|c|c|}
\hline \multirow{3}{*}{ Extent of Voting } & \multicolumn{6}{|c|}{ Comaronity Imphication Type } \\
\hline & \multicolumn{3}{|c|}{$3-4$} & \multicolumn{3}{|c|}{$1-2$} \\
\hline & $22-39$ & 40.64 & 65 and over & $22-39$ & $40-64$ & 65 and over \\
\hline $\begin{array}{l}3-4 \ldots \ldots \ldots \ldots \ldots \ldots \\
1-2 \\
0, \ldots \ldots \ldots \ldots \ldots \ldots \ldots\end{array}$ & $\begin{array}{l}69 \\
17 \\
14\end{array}$ & $\begin{array}{r}90 \\
7 \\
3\end{array}$ & $\begin{array}{r}90 \\
0 \\
10\end{array}$ & $\begin{array}{l}38 \\
37 \\
25\end{array}$ & $\begin{array}{l}40 \\
10 \\
50\end{array}$ & $\begin{array}{l}42 \\
29 \\
20\end{array}$ \\
\hline Total............. & 100 & 100 & 100 & 100 & 100 & 100 \\
\hline $\begin{array}{l}\text { (Number of } \\
\text { Respondents).... }\end{array}$ & (29) & (29) & (10) & (8) & $(10)$ & (34) \\
\hline
\end{tabular}

TABLE XII

Political Activities (Other Than Voting) by Age and Community Implication (Per Cent)

\begin{tabular}{|c|c|c|c|c|c|c|}
\hline \multirow{3}{*}{$\begin{array}{l}\text { Number of Political } \\
\text { Activities (Other } \\
\text { than Voting) }\end{array}$} & \multicolumn{6}{|c|}{ CoMaunity ImpLication Trpe } \\
\hline & \multicolumn{3}{|c|}{$3-4$} & \multicolumn{3}{|c|}{$1-2$} \\
\hline & $22-39$ & $40-64$ & 65 and over & $22-39$ & $40-64$ & 65 and over \\
\hline 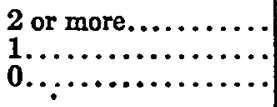 & $\begin{array}{l}38 \\
48 \\
14\end{array}$ & $\begin{array}{l}44 \\
28 \\
28\end{array}$ & $\begin{array}{l}50 \\
20 \\
30\end{array}$ & $\begin{array}{l}38 \\
12 \\
50\end{array}$ & $\begin{array}{r}0 \\
30 \\
70\end{array}$ & $\begin{array}{r}9 \\
29 \\
62\end{array}$ \\
\hline Total. ............. & 100 & 100 & 100 & 100 & 100 & 100 \\
\hline $\begin{array}{l}\text { (Number of } \\
\text { Respondents).... }\end{array}$ & (29) & (29) & (10) & (8) & (10) & (3i) \\
\hline
\end{tabular}


TABLE XIII

Progressivism by Age and Community Implication (Per Cent)

\begin{tabular}{|c|c|c|c|c|c|c|}
\hline \multirow{3}{*}{ Opinion } & \multicolumn{6}{|c|}{ Comaunity Implication Type } \\
\hline & \multicolumn{3}{|c|}{$3-4$} & \multicolumn{3}{|c|}{$1-2$} \\
\hline & $22-39$ & $40-64$ & 65 and over & $22-39$ & $40-64$ & 65 and over \\
\hline 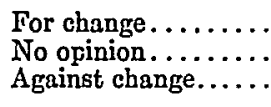 & $\begin{array}{l}47 \\
25 \\
28\end{array}$ & $\begin{array}{l}55 \\
22 \\
23\end{array}$ & $\begin{array}{l}58 \\
20 \\
22\end{array}$ & $\begin{array}{r}53 \\
38 \\
9\end{array}$ & $\begin{array}{l}33 \\
37 \\
30\end{array}$ & $\begin{array}{l}29 \\
45 \\
26\end{array}$ \\
\hline Total............. & 100 & 100 & 100 & 100 & 100 & 100 \\
\hline $\begin{array}{l}\text { (Number of } \\
\text { Responses). . }\end{array}$ & (116) & (116) & $(40)$ & (32) & $(40)$ & (136) \\
\hline
\end{tabular}

that the data are also consistent with still another interpretation. It could be said that two syndromes have been depicted, "caring," and "not caring" about one's home community, and that action in the local political arena is but a segment of the syndrome. In contrast, we account for political activity and opinion in terms of degree of access to those community structures which lead first to acceptance of norms and then to expression of this acceptance in appropriate action. In this view, access need not depend upon caring.

We can choose between these alternatives. It should follow from the "caring" interpretation that groups with little implication in the community would show less identification with it than groups which are more implicated. The "community responsibility" model leads to no such prediction; for from this point of view political participation is a function of access to the social structure, and the development of identification may be independent of whether one has access.

Fortunately, a ready, though approximate, indicator of identification with the community was available in answers to a question about whether the respondent took pride in being a Durhamite. Since old people and women have been characterized as having relatively less access than their counterparts to most of the resources of the society, we examined the distributions of positive claims to pride among homogeneous age and sex groupings. The findings reported in table fourteen clearly contradict the "care syndrome" interpretation, without negating the "community responsibility model." There is no difference in pride between the two sexes, while the old report feelings of pride significantly more than do the general sample members. Hence, it appears that people who "really care" may, nonetheless, be non-participants because their status attributes deprive them of access to forms of social participation that lead to such behavior. ${ }^{31}$ All this suggests that old persons behave and think differently from younger ones on the local political scene only in so far as they are less a part of the total community. Given equal membership, the findings suggest that the paradoxical political role of the aged might disappear.

${ }^{31}$ Both implication and voting were unrelated to identification with the community. 
TABLE XIV

Distribution of Community Pride Among Men and Women in the General and Old Samples

(Per Cent)

\begin{tabular}{|c|c|c|c|c|}
\hline \multirow{2}{*}{ Community Pride } & \multicolumn{2}{|c|}{ Man } & \multicolumn{2}{|c|}{ WOMEN } \\
\hline & General Sample & Old Sample & General Sample & Old Sample \\
\hline 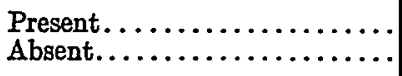 & $\begin{array}{l}70 \\
30\end{array}$ & $\begin{array}{l}89 \\
11\end{array}$ & $\begin{array}{l}79 \\
21\end{array}$ & $\begin{array}{l}90 \\
10\end{array}$ \\
\hline Total................. & 100 & 100 & 100 & 100 \\
\hline (Number of Respondents)..... & (76) & (44) & (117) & $(92)$ \\
\hline
\end{tabular}

\section{CONCLUSION}

The citizen's implication in the total life of the community has predicted, with relative precision, not only rates of political activity and opinion formation but also the direction of positions taken on issues. Through the use of old age as a critical case, the implication approach has pointed a way towards understanding disproportionate rates of political deviance in specific segments of the community. These results indicate the necessity of considering the civic responsibility model in understanding the political process. They also clarify another point recently made in political theory.

In his synthesis of empirical voting studies, Parsons $s^{32}$ attempted to account for the relative harmony that is rapidly established after a partisan campaign. $\mathrm{He}$ attributes such equilibration (x) to shared belief in the democratic process (generalized norms of civic responsibility in our terms), (2) to general disinterest in political issues, and (3) to the cross-pressures that arise from the fact that the individual belongs to numerous sub-groups and consequently interacts with members of all (usually two) major factions. The findings of the present study extend his theory by suggesting that the range of the individual's participation in such sub-groups not only may make for uncertainty and tolerance but may also increase his exposure to the norms of civic responsibility. This, in turn, indicates the desirability of ascertaining the circumstances under which a heightened range of exposure leads to political inactivity and apathy, and those under which the same experiences result in heightened activity and interest.

Finally, the use of the extent of implication as a predictor of local political activity and opinion in this community suggests that political activity was only a special case of community activity in general. By this we mean that the greater the number of ways the individual is tied to the community, the greater will be his access to any of its norms, political or other. The more parts of a total structure to which the individual is exposed, the more will he be oriented to the norms of the whole.

${ }^{32}$ Parsons, "Voting" and the Equilibrium of the American Political System, in EvaENE BuRDIcK \& Arthur J. Brodbeck (Eds.), American Voting Behavior 180-220 (1959). 